\title{
Effect of torrefaction temperature on energy properties of spent coffee ground
}

\author{
Natthanant Bangkha ${ }^{1}$, Wanphut Saechua ${ }^{1}$, Tharathip Nuamyakul ${ }^{1}$, and \\ Jiraporn Sripinyowanich Jongyingcharoen ${ }^{1 *}$ \\ ${ }^{1}$ King Mongkut's Institute of Technology Ladkrabang, Faculty of Engineering, \\ Department of Agricultural Engineering, Thailand
}

\begin{abstract}
The aim of this research was to investigate the effect of torrefaction temperature on 4 energy properties as high heating value (HHV), enhancement factor, solid yield, and energy yield of spent coffee ground (SCG). Four different torrefaction temperatures $(200,250,300$, and $350^{\circ} \mathrm{C}$ ) were selected. Torrefaction process was conducted at the heating rate of $10^{\circ} \mathrm{C} / \mathrm{min}$. HHV and enhancement factor were the highest when SCG was torrefied at the highest temperature of $350^{\circ} \mathrm{C}$. However, at this temperature, solid and energy yields were the lowest. Torrefaction temperature highly affected these four energy properties with $\mathrm{R}$ of higher than 0.9. Regression models representing the relationship between torrefaction temperature and $\mathrm{HHV}$ and energy yield were $\mathrm{HHV}=0.0519 \mathrm{~T}+15.917, \mathrm{R}^{2}=0.9483$ and energy yield $=-0.2743 \mathrm{~T}+155.1$, $\mathrm{R}^{2}=0.9976$. These models are helpful for prediction of the energy properties of SCG undergoing torrefaction process in the studied temperature range.
\end{abstract}

\section{Introduction}

Biomass is a natural energy resource which can be used as a substitute for fossil fuel. It may come from agricultural wastes such as rice straw, coconut shell, bagasse or energy crops as Napier grass. Biomass can be divided into three types based on the states of matter: liquid, solid and gaseous fuels as follows. Liquid fuels include ethanol, biodiesel, pyrolysis oil, etc. Solid fuels include charcoal, terrified biomass, biochar, etc. Gaseous fuels include biogas $\left(\mathrm{CH}_{4}, \mathrm{CO}_{2}\right)$ and syngas $\left(\mathrm{CO}, \mathrm{H}_{2}\right)[1]$.

Coffee is one of agricultural crops that is consumed worldwide. The important cultivation areas of coffee are in Brazil, Vietnam, Colombia and Indonesia, which constitute $66 \%$ of the total world export. Thailand ranks $6^{\text {th }}$ in instant coffee export. Coffee businesses in Thailand have grown and expanded, and new coffee business increased $37.71 \%$ comparing with 2017 [2]. When coffee demanding increases, wastes are also increased subsequently. High heating value (HHV) of spent coffee ground (SCG) with low moisture content $(3.16 \%$ $\mathrm{wb}$ ) is $21.77 \mathrm{MJ} / \mathrm{kg}$ [3], which is higher than HHV of lignite $(14.65-19.30 \mathrm{MJ} / \mathrm{Kg}$ ) [4]. It is obvious that SCG is a good source of heat energy.

\footnotetext{
* Corresponding author: jiraporn.jo@kmitl.ac.th
} 
Torrefaction is a pre-treatment process of biomass. Under torrefaction process, bonded and unboned moisture and volatile fraction (mostly hemicellulose and some of lignin) release and turn into solid. Torrefied biomass generally composes of cellulose and lignin which provide higher carbon content in relative to original biomass [5]. Torrefaction is therefore becoming a significant process for refining woody biomass or industry residue for energy improvement [6].

According to previous works, the effect of torrefaction temperature on thermochemical properties and true density of torrefied coffee residue showed carbon content increased mostly at torrefied temperature range 290 to $320^{\circ} \mathrm{C}$ [7]. Matali et al. [8] studied the influence of torrefaction process parameters on physico-chemical properties of two biomass materials, i.e. oil palm frond (non-woody biomass) and Leucaena Leucocephala, and found that if the torrefaction temperature increased, their energy content raised, but mass reduced.

In this work, SCG was subjected to torrefaction process at the different temperatures from 200 to $350^{\circ} \mathrm{C}$. The aim of this work was to investigate the effect of torrefaction temperature on energy properties of SCG, including HHV, enhancement factor, solid yield, and energy yield. Correlations and relationships among the torrefaction temperature and energy properties were also determined.

\section{Materials and methods}

\subsection{Material preparation}

SCG (66 $2 \%$ wb), Robusta variety, was provided by Khao Shong Industry 1979 Co., Ltd. (Samutprakarn, Thailand). It was dried in a hot air oven (ULM 500, Memmert $\mathrm{GmbH}+\mathrm{Co} . \mathrm{KG}$, Schwabach, Germany) at $105^{\circ} \mathrm{C}$ until the moisture content was $5 \pm 2 \% \mathrm{wb}$. Then, the dried SCG was sieved through a $425-\mu \mathrm{m}$ mesh screen in order to obtain particle size lower than $425 \mu \mathrm{m}$ based on prior research of torrefied SCG which was in the range of 400 to $500 \mu \mathrm{m}$ [3],[7]. The sieved SCG was kept in an air-tight container at room temperature prior to further experiments.

\subsection{Thermogravimetric analysis}

SCG $(20 \pm 1 \mathrm{mg})$ was filled in an aluminum oxide $\left(\mathrm{Al}_{2} \mathrm{O}_{3}\right)$ crucible and placed in a thermogravimetric analyzer (TG209F3 Tarsus, Netzsch, Germany). Firstly, the sample was maintained at $33^{\circ} \mathrm{C}$ for $5 \mathrm{~min}$. Then, the temperature was increased to $700^{\circ} \mathrm{C}$ with the constant heating rate of $10^{\circ} \mathrm{C} / \mathrm{min}$ and hold at this temperature for $30 \mathrm{~min}$. After that, oxygen gas was purged for $15 \mathrm{~min}$ in order to complete the combustion process. Data of weight loss versus temperature were obtained and used to describe thermal decomposition behaviour of SCG.

\subsection{Torrefaction process}

To prepare torrefied SCG, $5 \pm 1 \mathrm{~g}$ of SCG sample was filled into a crucible and placed in an electric furnace (JSMF-45T, JSR, Korea). In the first stage of the process, the sample was dried at $105^{\circ} \mathrm{C}$ for $1 \mathrm{~h}$. Then, the crucible was covered and the temperature of the furnace was increased with the heating rate of $10^{\circ} \mathrm{C} / \mathrm{min}$ to the predetermined torrefaction temperature $\left(200,250,300\right.$, and $\left.350^{\circ} \mathrm{C}\right)$. The torrefaction duration was $30 \mathrm{~min}$. After completing the torrefaction process, the sample was left inside the desiccator to be cooled down to ambient temperature and used for further analysis. 


\subsection{High heating value measurement}

HHV of SCG was measure using a bomb calorimeter (C200, IKA, Germany) in isoperibol mode at room temperature. In this mode, the HHV measurement was conducted at the constant temperature of bomb calorimeter and surrounding environment [9]. After the combustion process, released heat from the sample caused temperature change and the temperature difference was used to evaluate the HHV. HHV of non-torrefied SCG was also determined as a control sample.

\subsection{Enhancement factor}

Enhancement factor was used to define energy output of torrefied biomass in relative to nontorrefied biomass. It can be calculated using Equation (1).

$$
\text { Enhancement factor }=H H V_{\text {torrefied } S C G} / H H V_{\text {non-torrefied } S C G}
$$

\subsection{Solid yield}

Solid yield was defined as the weight ratio of biomass undergoing the torrefaction process and raw biomass as shown in Equation (2).

$$
\text { Solid yield }(\%)=\left(\text { Weight }_{\text {torrefied SCG }} / \text { Weight }_{\text {non-torrefied SCG }}\right) \times 100
$$

\subsection{Energy yield}

Energy yield was used to describe the energy retention of biomass and can be calculated as follows:

$$
\text { Energy yield }(\%)=\text { Solid yield } x \text { Enhancement factor }
$$

\subsection{Statistical analysis}

All the experiments were triplicated. Analysis of Variance (ANOVA) and Duncan's New Multiple Range test were used for hypothesis testing of mean at the $95 \%$ confidence level. Pearson's correlation coefficients were determined to describe the relationship between two factors. Linear regression analysis was used to create prediction models between torrefaction temperature and HHV and energy yield of SCG. Performance of the prediction models was indicated by coefficient of determination $\left(\mathrm{R}^{2}\right)$ [9].

\section{Results and discussion}

\subsection{Thermal behaviour}

Thermal decomposition behaviour of biomass can be represented by percent residual mass of the material as a function of decomposition temperature. The residual mass data of SCG reflects its chemical composition and are very helpful to describe other energy properties of the SCG. TGA curve of SCG of this study is shown in Figure 1. It is as expected, the thermal decomposition of SCG was a gradual process with different chemical decomposition stages. The first stage of about $5 \%$ mass loss, which was the loss of moisture and loose constituents, was observed from $33^{\circ} \mathrm{C}$ to $220^{\circ} \mathrm{C}$. Thereafter, substantial drop in mass to below $40 \%$ was 
observed in the second stage from $220^{\circ} \mathrm{C}$ to $400^{\circ} \mathrm{C}$. These can be implied that this temperature range impacted on lignocellulosic structure of SCG. The decomposition of hemicellulose of SCG started from 220 to $310^{\circ} \mathrm{C}$ while the cellulose and lignin decomposition started from 350 to $430^{\circ} \mathrm{C}$. Tsai and Liu [7] also reported similar thermal behaviour of SCG, hemicellulose and cellulose components degraded within the temperature range of $227-300^{\circ} \mathrm{C}$ and $300-397^{\circ} \mathrm{C}$, respectively.

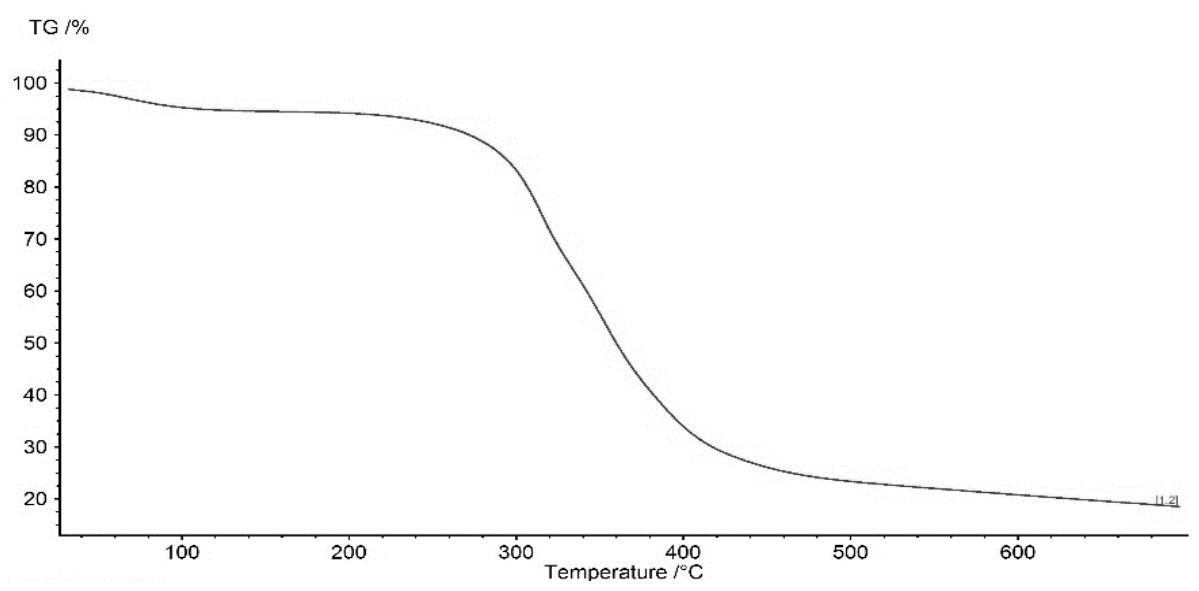

Fig. 1. TGA curve of non-torrefied SCG.

\subsection{High heating value}

HHV data of torrefied SCG are shown in Figure 2 with the HHV of non-torrefied SCG as a control. It was obviously seen that an increase in torrefaction temperature significantly resulted in an increase in HHV of SCG $(\mathrm{p} \leq 0.05)$ while the non-torrefied SCG gave the lowest HHV. This result proved that torrefaction process helped enhancing HHV, which was the heat released by complete combustion of fuel. The reason of an increase in HHV was the decrease in hydrogen and oxygen contents and increase in carbon content when decomposing the SCG during the torrefaction process [7]. It is interesting that HHV of torrefied SCG obtained in this study $(32.03 \mathrm{MJ} / \mathrm{kg})$ was higher than those reported by Buratti et al. [5] (31.68 $\mathrm{MJ} / \mathrm{kg}$ ) at the same temperature of $300^{\circ} \mathrm{C}$.

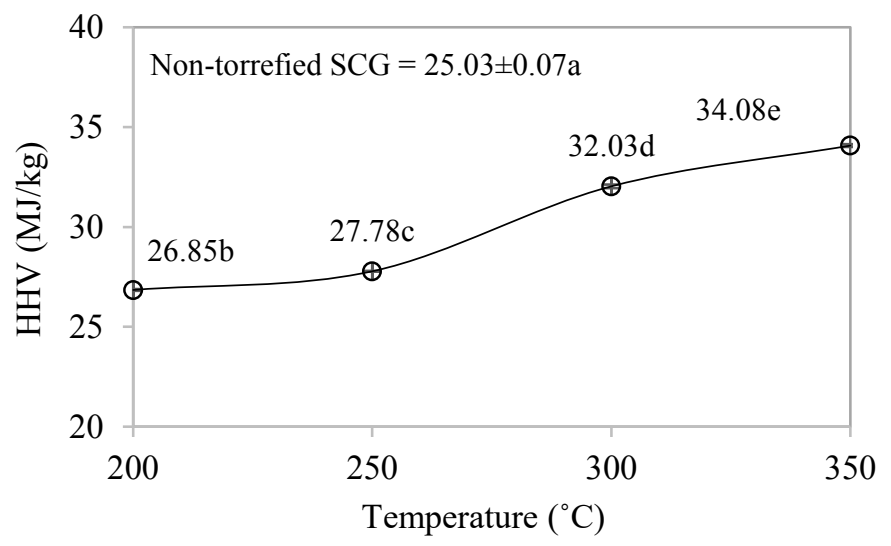

Fig. 2. HHV of torrefied SCG as a function of torrefaction temperature. 


\subsection{Enhancement factor}

Increased HHV of torrefied SCG as compared to HHV of non-torrefied SCG can be presented in term of enhancement factor. As shown in Figure 3, at the torrefaction temperature lower than the decomposition temperature of SCG, i.e. $200^{\circ} \mathrm{C}$, the enhancement factor was only 1.07. High enhancement factors could be clearly obtained by torrefaction of SCG at the temperature higher than $300^{\circ} \mathrm{C}$ as its hemicellulose was decomposed and carbon content was increased as shown in the TGA data described above.

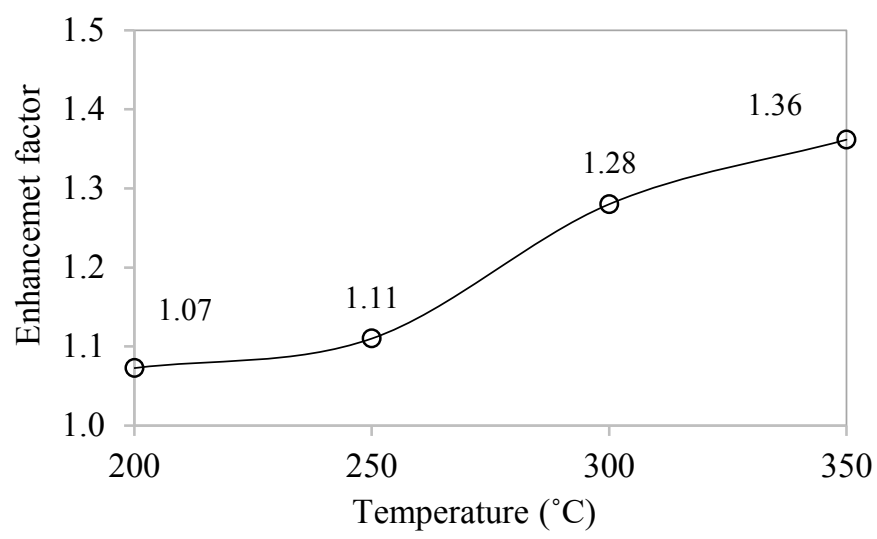

Fig. 3. Enhancement factor of torrefied SCG as a function of torrefaction temperature.

\subsection{Solid yield}

Effect of torrefaction temperature on solid yield of SCG is shown in Figure 4. Negative relationship between torrefaction temperature and solid yield was observed. The highest solid yield of about $93 \%$ was obtained at the lowest torrefaction temperature of $200^{\circ} \mathrm{C}$. This result was correspondent to what provided by TGA that biomass decomposition started at the process temperature of $220-310^{\circ} \mathrm{C}$, which is higher than $200^{\circ} \mathrm{C}$. By the way, the solid yields of SCG at the torrefaction temperature of $300^{\circ} \mathrm{C}$ and $350^{\circ} \mathrm{C}$ were $56.93 \%$ and $43.07 \%$, respectively. These may be the depolymerization of hemicellulose, which led to partial carbonization and volatilization of tar products derived from the lignocellulosic components of coffee residue [7]. TGA curves could be used to describe the results of low solid yields at these conditions as well. At $300^{\circ} \mathrm{C}$, hemicellulose degradation occurred and caused great amount of weight loss. 


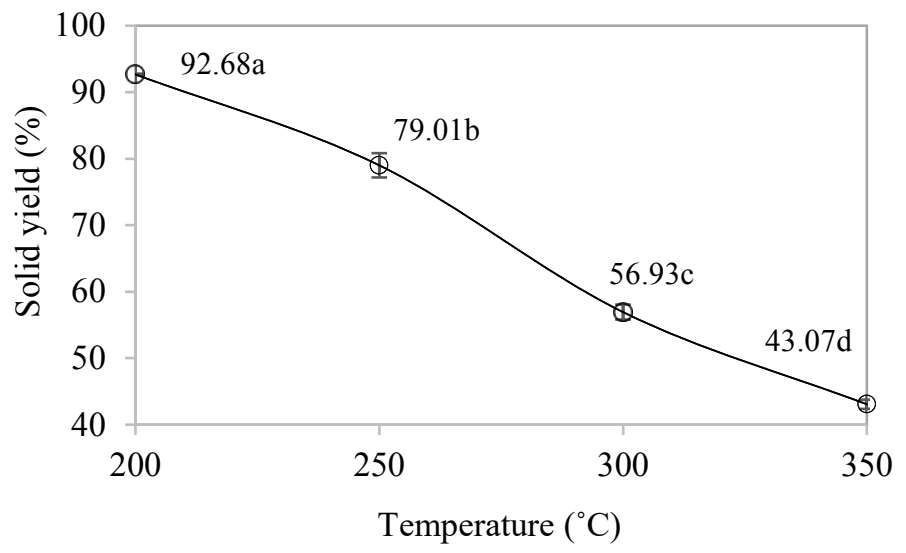

Fig. 4. Solid yield of torrefied SCG as a function of torrefaction temperature.

\subsection{Energy yield}

Energy yield is a term to describe energy retention of torrefied biomass. After the torrefaction process, some energy components lose and lead to lower energy yield of the biomass [1]. According to Figure 5., The energy yield decreased due to the decomposition of biomass under the torrefaction process, i.e. higher torrefaction temperature, higher amount of mass losses. Based on Equation (1) of 2.3 for energy yield calculation, energy yield mostly depends on mass yield value [8], thus the torrefaction temperature of $350^{\circ} \mathrm{C}$, gave both the lowest solid yield and energy yield. According to the previous experiment of Zhang et al. [3], similar trend of decreased energy yield with an increase in torrefaction temperature was observed.

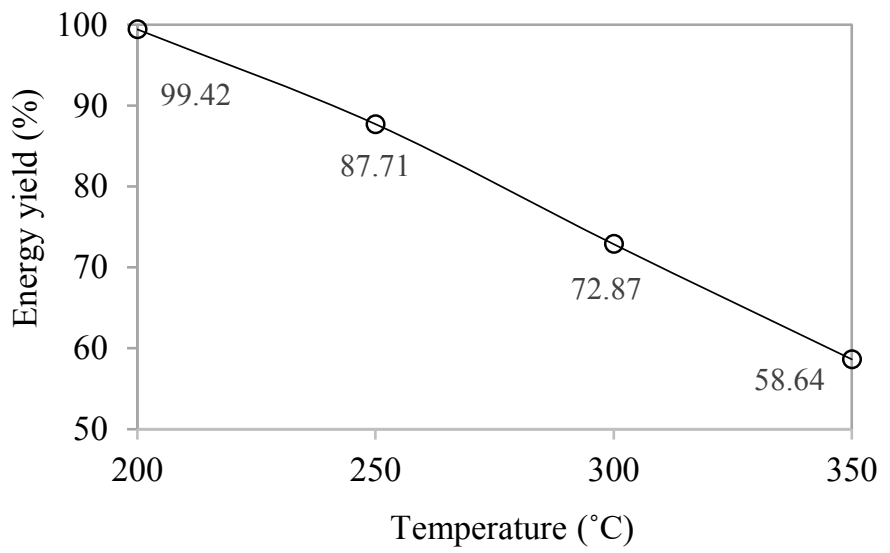

Fig. 5. Energy yield of torrefied SCG as a function of torrefaction temperature.

\subsection{Correlation among torrefaction temperature and energy properties}

The relationships between torrefaction temperature and different energy properties of torrefied SCG are shown in Table 1. in terms of Pearson correlation coefficients. Torrefaction temperature was positively correlated with $\mathrm{HHV}$ and enhancement factor, but negatively 
correlated with solid yield and energy yield. The correlation coefficients of higher than 0.9 for each pair of torrefaction temperature and the other energy parameter were obtained. This suggests that all the energy properties of SCG were substantially dependent on the torrefaction temperature. The energy properties of torrefied SCG could be predicted using the torrefaction temperature. Regression plots between torrefaction temperature and HHV and energy yield are presented in Figure 6 and Figure 7, respectively. The prediction models are shown in the plots with high coefficient of determination, which confirms that the HHV and energy yield can be accurately determined using the torrefaction temperature.

Table 1. Pearson correlation coefficients among different parameters.

\begin{tabular}{|c|c|c|c|c|c|}
\hline & Temperature & HHV & $\begin{array}{c}\text { Enhancement } \\
\text { factor }\end{array}$ & $\begin{array}{c}\text { Solid } \\
\text { yield }\end{array}$ & $\begin{array}{c}\text { Energy } \\
\text { yield }\end{array}$ \\
\hline HHV & $0.974^{*}$ & & & & \\
\hline Enhancement factor & $0.974^{*}$ & $1.000^{* *}$ & & & \\
\hline Solid yield & $-0.995^{* *}$ & $-0.989^{*}$ & $-0.990^{*}$ & & \\
\hline Energy yield & $-0.999^{* *}$ & $-0.982^{*}$ & $-0.982^{*}$ & $0.997^{*}$ & \\
\hline
\end{tabular}

$*$ and $* *$ means the correlations are significant at $\mathrm{p}<0.05$ and $\mathrm{p}<0.01$ levels, respectively.

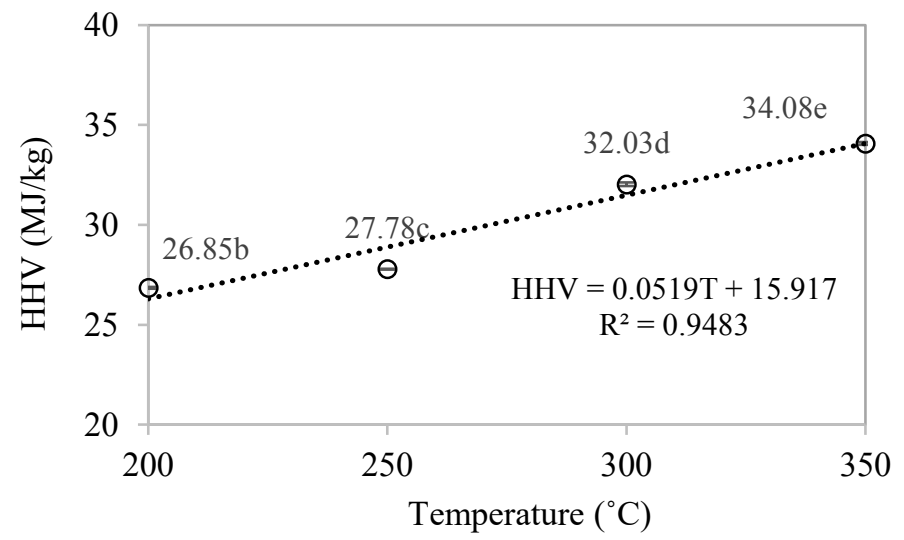

Fig. 6. Regression model of HHV and torrefaction temperature.

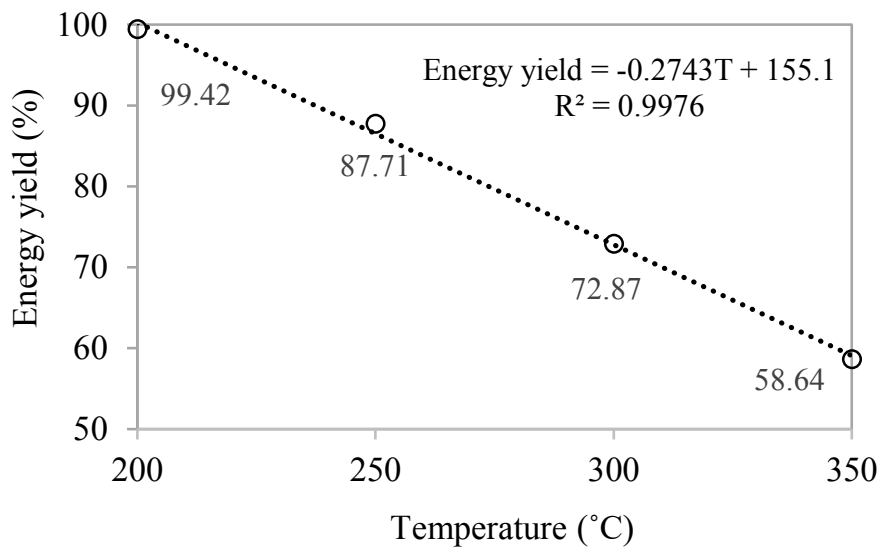

Fig. 7. Regression model of energy yield and torrefaction temperature. 


\section{Conclusions}

At the torrefaction temperature of $200-350^{\circ} \mathrm{C}, \mathrm{HHV}$, enhancement factor, solid yield, and energy yield of SCG were in the ranges of $26.85-34.08 \mathrm{MJ} / \mathrm{kg}, 1.07-1.36,92.68-43.07 \%$, and $99.42-58.64 \%$, respectively. HHV of torrefied SCG was higher than non-torrefied SCG, which was $25.03 \mathrm{MJ} / \mathrm{kg}$. It is significant that torrefaction process could enhance energy properties of SCG. High correlation coefficients of over 0.9 were obtained between torrefaction temperature and every energy parameter. Regression models for predicting HHV and energy yield using know torrefaction temperature were generated with high coefficient of determinations of over 0.9 as well.

The author thanks Department of Agricultural Engineering, Faculty of Engineering, King Mongkut's Institute of Technology Ladkrabang for laboratory supports.

\section{References}

1. P. Basu, Biomass Gasification, Pyrolysis and Torrefaction (Academic Press, 2018)

2. Unknown, Coffee production business, D.o.B. Development, (2019)

3. C. Zhang, S. Ho, W. Chen, Y. Xie, Z. Liu, J.Chang. Applied Energy. 220, 598-604. (2018)

4. J. Groppo, Coal Combustion Products (CCP's), (Woodhead Publishing, 2017)

5. C. Buratti, M. Barbanera, E. Lascaro, F. Cotana. Waste Management. 73, 523-534. (2018)

6. A. Eseyin, P. Steele, C. Pittman Jr., K. Ekpenyong. Journal of Biofuels. 7 (2016)

7. W.-T. Tsai, S.-C. Liu, Journal of Analytical and Applied Pyrolysis. 102,47-52. (2013)

8. S. Matali, N.A. Rahman, S.S. Idris, N. Yaacob, A.B. Alias. Procedia Engineering, 148,671-679. (2016)

9. J. Posom. Rapid analysis of energy characteristic of biomass using near infrared spectroscopy. (2017) 